\title{
HEAT STRESS IN POULTRY INDUSTRY
}

\author{
Miloš Kapetanov ${ }^{1}$, Marko Pajić, Dragana Ljubojević, Miloš Pelić \\ Scientific Veterinary Institute „Novi Sad“, Novi Sad, Republic of Serbia
}

\section{Abstract}

The results of our 15-year long research on the effects of global warming in our region that relies on the database obtained from the Republic Hydrometeorological Service of the Republic of Serbia strongly suggested changes in the pattern of disease events associated with inevitable occurrence of heat stress in poultry regardless of the species and category. Having in mind the accelerating global warming and geographic position of Serbia the occurrence of frequent cyclical and intense meteorological extremes is expected (Kapetanov et al., 2011; Kapetanov et al., 2013; Kapetanov et al., 2013). In our country and surrounding regions characterized by continental climate, the risk from the heat stress in poultry production is limited to summer months. Still, summer period has been getting longer and is associated with increasing trend of tropical days and annual trend of global warming spreading of $0.2^{\circ}$ geographic latitude. Heat stress of poultry is one of the most challenging problems of poultry production causing substantial damages and affecting all parameters of production performance and is often associated with sudden and massive deaths. Having in mind the aforementioned data, the objective of our research was monitoring of changes in mortality structure associated with temperature oscillations during production process with an aim of emphasizing some major sources, consequences and preventive measures related to heat stress.

Key words: heat stress, poultry, prevention

\footnotetext{
${ }^{1}$ Corresponding author: milos@niv.ns.ac.rs
} 


\title{
TOPLOTNI STRES U ŽIVINARSKOJ PROIZVODNjI
}

\author{
Miloš Kapetanov, Marko Pajić, Dragana Ljubojević, Miloš Pelić \\ Naučni institut za veterinarstvo „Novi Sad“, Novi Sad, Srbija
}

\section{Kratak sadržaj}

Tokom naših petnaestogodišnjih istraživanja, koja se odnose na uticaj globalnog otopljavanja u okruženju, pri čemu su korišćeni podaci Republičkog Hidrometorološkog Zavoda Srbije, došli smo do rezultata koji ukazuju na izmenjenu strukturu pojavljivanja bolesti uz neizostavno prisustvo toplotnog stresa u živinarstvu, bez obzira na vrstu i kategoriju. Imajući u vidu nastupajuće globalno otopljavanje, koje uzima maha, i geografski položaj Srbije zasigurno treba očekivati češća ciklična, pa čak i intezivnija pojavljivanja meteoroloških ekstrema (Kapetanov i sar., 2011; Kapetanov $i$ sar., 2013; Kapetanov i sar., 2013). U našoj zemlji, kao i svim zemljama okruženja koje imaju kontinentalnu klimu, mogućnost toplotnog stresa u živinarskoj proizvodnji postoji samo u jednom delu godine - leti. Međutim, letnji period kao godišnje doba traje duže sa povećanjem broja tropskih dana i sa godišnjim trendom širenja globalnog otopljvanja za $0,2^{0}$ gegrafske širine. Toplotni stres živine je jedan od problema koji u živinarstvu prouzrokuje velike štete, narušavajući sve proizvodne perfomanse i koga prate nagla i masovna uginuća. S obzirom da nam je letnja sezona prošla, podsećanje na osnovne uzroke, posledice i načine sprečavanja toplotnog stresa i izvučena iskustva mogla bi biti od velike koristi.

Ključne reči: :

\section{INTRODUCTION}

Main heat sources in housing facility include external temperature of the air released into the room, emission from heated roofs and walls and heat released by the birds themselves. External air temperature is quite beyond our influence; however, certain measures for cooling walls and roofs should be taken. Still, the heat released by the birds themselves represents the most dominant heat source in the facility. Complete poultry feed mixtures are energyrich - they are often compared with a chocolate-glazed cake. The energy in complete feed formulations should provide basic physiological function of the body (breathing, blood circulation, maintenance of body temperature, immunity, etc.), that is, both maintenance and productive functions. Poultry is con- 
sidered highly effective species as only $25 \%$ of dietary energy is necessary for satisfying their maintenance demands. However, $75 \%$ of energy is an excess, which is released by birds to maintain normal body temperature.

When the temperature in poultry house exceeds $27^{\circ} \mathrm{C}$, the birds begin to feel uncomfortable and start panting. Ambient temperature in poultry house above $27^{\circ} \mathrm{C}$ makes birds feel uncomfortable and they start panting, whereas temperatures above $30^{\circ} \mathrm{C}$ make proper heat release highly difficult. It is particularly problematic when high temperatures are associated with high air humidity.

Hence, heat stress of poultry is one of the most challenging problems of poultry production causing substantial damages and affecting all parameters of production performance and is often associated with sudden and massive deaths. Having in mind the aforementioned data, the objective of our research was monitoring of changes in mortality structure associated with temperature oscillations during production process with an aim of emphasizing some major sources, consequences and preventive measures related to heat stress

\section{MATERIAL AND METHODS}

Throughout the period of several years, the presence of diverse bacterial and viral diseases as well as production characteristics was monitored in the territory of South Bačka and Srem Districts. The monitoring encompassed the mortality structure and production performance of poultry of light and heavy genotype including different categories and age of birds in the industrial production system.

The baseline for presenting the achieved production performance was the Table dating from 1995, which depicts the structure of economic losses associated with particular diseases in broiler production. Another table depicts the mortality structure in broiler chickens at present time characterized by evident climatic changes due to global warming. The tables used for comparing mortality structure and economic losses pertain to summer production lots.

Production features were assessed using following parameters: feed conversion, mortality, final weight and length of fattening period. The presence of infectious diseases was confirmed using laboratory assays as well as bacterial, serological and virological examination. Technopathies observed during the production process along with laboratory examinations were of importance for determining mortality structure. All aforementioned parameters were monitored throughout the cited time period, whereas hydrometeorological conditions, i.e., temperature oscillations, were variables influencing the poultry production process. 


\section{RESULTS AND DISCUSSION}

During the research period, presence of diverse viral, bacterial and parasitic diseases as well as diseases of other etiologies were monitored, including Pseudo-Poultry Plague, Gamboro Disease, Salmonellosis, E.coli, Coccidiosis, Uricosis, technological fallout and diseases of unknown etiology (Table 1).

Table 1 Structure of economic losses in a summer production lot according to the disease

1995

\begin{tabular}{|l|c|c|}
\hline \multicolumn{1}{|c|}{ Disease type } & Disease (\%) & Economic losses (\%) \\
\hline Salmonellosis & 1.19 & 1.19 \\
\hline Uricosis & 2.23 & 2.23 \\
\hline Omphalitis & 2.96 & 2.96 \\
\hline Technological fallout & 11.5 & 11.5 \\
\hline Coccidiosis & 25.00 & 25.00 \\
\hline Mycotoxicosis & - & - \\
\hline Coli infection & 32.94 & 32.94 \\
\hline Apoplexia & 8.74 & 8.74 \\
\hline Gamboro disease & - & - \\
\hline Other & 15.39 & 15.39 \\
\hline TOTAL & 100 & 100 \\
\hline
\end{tabular}

Table 2 displays the data on monitoring production features and mortality structure during the research period. Analysis of mortality structure indicated the presence of some diseases that had not been previously recorded, such as Mycotoxicosis, Aspergillosis, Pox, Histomoniasis and heat shock and their participation in economic losses is presented (Table 2). 
Table 2. Structure of economic losses in a summer production lot according to the disease in 2015

\begin{tabular}{|l|c|c|}
\hline \multicolumn{1}{|c|}{ Disease type } & Disease (\%) & Economic losses (\%) \\
\hline Salmonellosis & 1.10 & 1.10 \\
\hline Uricosis & 1.29 & 2.29 \\
\hline Technological fallout & 10.0 & 10.00 \\
\hline Coli infection & 30.90 & 30.90 \\
\hline Apoplexia & 10.78 & 10.78 \\
\hline Gamboro disease & - & - \\
\hline Mycotoxicosis & 25.25 & 25.25 \\
\hline Aspergillosis & 2.96 & 2.96 \\
\hline Pox & 1.30 & 1.3 \\
\hline Histomoniasis & 1.25 & 1.25 \\
\hline Heat shock & 15.39 & 15.39 \\
\hline TOTAL & 100 & 100 \\
\hline
\end{tabular}

As obvious in presented tables, some of the diseases were less prevalent in the period of less pronounced heat stress. Contrary to that, the period of increased temperatures is associated with higher incidence of some diseases. Also, our research revealed decreased antimicrobial susceptibility of particular bacterial species, which is likely due to increased application of antimicrobial drugs on the farms. The administration of antibiotics has commonly been unjustified as the diseases were provoked by heat stress (Stojanov et al., 2008). This problem is closely related to the implementation of appropriate prophylactic measures, since climatic changes induced variations in the presence and geographical distribution of particular disease-vectors that were formerly unknown.

Understanding of the physiology of poultry and their potential defense mechanisms is the prerequisite for adequate prevention of heat stress. 


\section{POULTRY DEFENSE MECHANISM AGAINST HEAT STRESS}

1. Emission - certain portion of heat is released through emission (radiation) by releasing the temperature into the environment via the skin. To increase temperature release by emission poultry often lift their wings away from their bodies to expose the skin areas that have least feathers. Such behavior can be effective only provided that external temperature is lower than body temperature. If the temperature difference is small, i.e., the air overheated, the effects of cooling by radiation is negligible. Airflow can be very helpful, i.e. "moving air" surrounding the poultry actually "removes" the warmest layer immediately around the body and enables further release of the heat. As this most effective way of releasing heat to maintain the body temperature is directly linked with appropriate ventilation, it should be taken into consideration when planning the ventilation capacity of the housing facility. Heat release by radiation is not possible when poultry is overcrowded or the space is too small, which prevents the airflow around the body. These issues should be considered when planning the population density and the rate of meat production per $\mathrm{m}^{2}$ !

2. Evaporation (panting) - Regulation of heat-balance by evaporation starts after other way of cooling fails. The bird starts to pant slowly and then increases the intensity and speed of panting. In this manner, the birds can release over $60 \%$ of moist air from the body via the lungs and thus decrease the body temperature (Fig. 1)

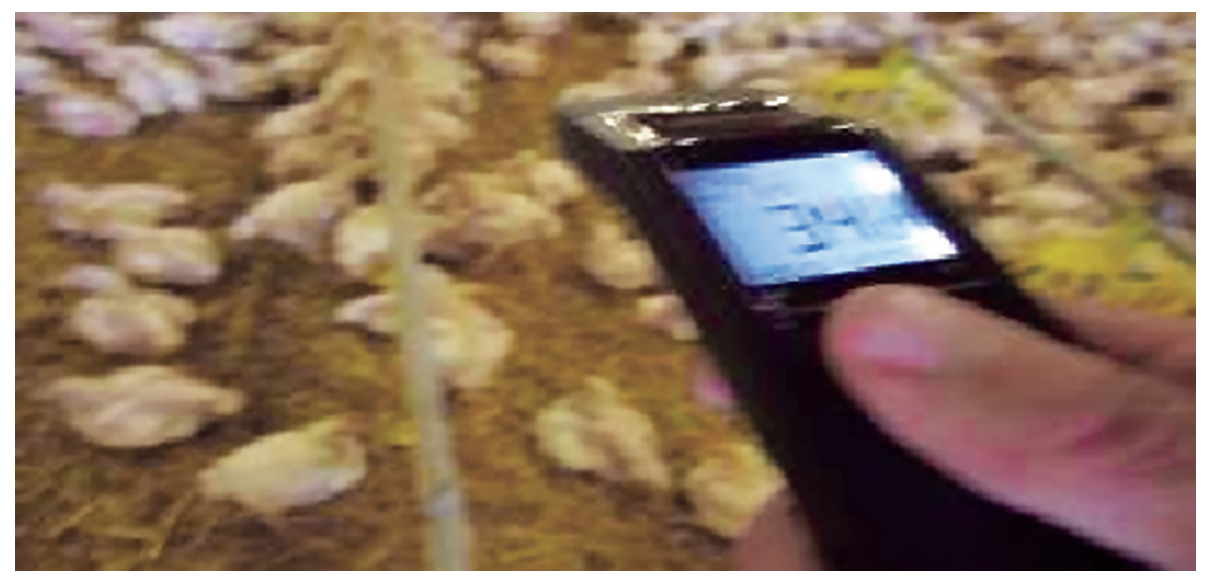

Figure 1. High temperature of $34^{\circ} \mathrm{C}$ measured in housing premise 
Highly saturated air (high relative humidity in the premises) reduces the effectiveness of panting and evaporative heat loss. Panting requires energy use, thus, even if the heat stress has been reduced production results will be jeopardized in this period (Levent and Porter, 2005; Simmons et al., 1996).

3. Conduction (heat transfer) - some part of the heat can be transmitted through skin contact with cooler surfaces. The birds lean against cold wall or watering system or (if kept in cages) against cage walls. Dry and loose litter enables the poultry to reach the cold floor beneath and lay down on it. Wet litter only contributes to additional heating! Anyway, the heat release by conduction is relatively weak unless floor cooling systems are available.

4. Reducing feed intake - Under conditions of high ambient temperature the poultry reduce the feed intake to decrease heat stress, which negatively affects the production performance.

5. Increase water consumption -In conditions of increased environmental temperature water intake significantly increases as a consequence of great water loss through panting. Moreover, bird's metabolism undergoes changes by increasing kidney activity to survive with heat stress - water uptake and output is increased.

In addition to understanding of poultry physiology and their defense mechanisms against increased temperature, implementation of appropriate measures for alleviating heat stress in poultry houses are required.

\section{MEASURES FOR ALLEVIATING HEAT STRESS}

1. Density is considered one of the crucial factors. The overcrowding in poultry production facilities is harmful in many ways - huge number of birds releases more heat, great density of poultry does not allow to birds to keep distance from each other thus reducing the effectiveness of heat release by radiation. If the birds are too close to each other the effects of heat release are reduced by even $40 \%$, which is apparent in overcrowded premises. The airflow surrounding the birds, with the purpose of "taking away" excess heat around the body is obstructed in case of too dense bird population. In that respect, to obtain good production performance, i.e., final body weight of chickens, the number of birds should be carefully planned during summer months!

Ventilation is plays crucial role. To adequately handle the heat wave, the capacity of the ventilation system needs to be adjusted to the number of bird po- 
pulation and the exhaust fans must be functional and properly positioned. Good ventilation system should be designed and installed as an integral part of a construction project, but it can be additionally adjusted and upgraded if necessary. The number and capacity of exhaust fans should be adjusted to the number, size and position of air intakes. The airflow rate also contributes to heat removal around the birds, which is one of the major advantages of tunnel ventilation system. Airflow is the prerequisite for successful cooling. An adequate adjustment of airflow rate with poultry species and age is of critical importance during hot summer season (Donald, 2000). Optimal airflow in production facilities is and imperative when speaking of tunnel ventilation, especially to alleviate negative effects of high humidity resulting from evaporation heat release and in adult poultry, which is covered with feathers and thus more difficultly remove the air surrounding the body. Considering the characteristics of young birds such as rather low humidity, limited amount of heat they produce, lack of feathers and lesser need for space, an adequate airflow rate for young birds is somewhat lower and should provide a comfortable and pleasant environment. Too much (high speed) of airflow is not comfortable for birds, thus, it is not recommended in normal environmental conditions. The first symptom of an inadequate fan speed and high airflow rate is dehydration in young birds.

Installation of an alarm system, which activates in case that fans stop to operate can prevent huge damage because in the period of extreme heats, one should react PROMPTLY and FASTLY! Thus, the alarm system is highly valuable along with the system that provides automatic activation for the generator in case of power supply problems.

Pad cooling systems are installed on the air inlet openings and provide cooling by air flowing into the house through the pad moisten with cold water. Evaporative cooling pads are currently the most effective and efficient systems for cooling poultry houses and is installed at many farms. (Figure 2)

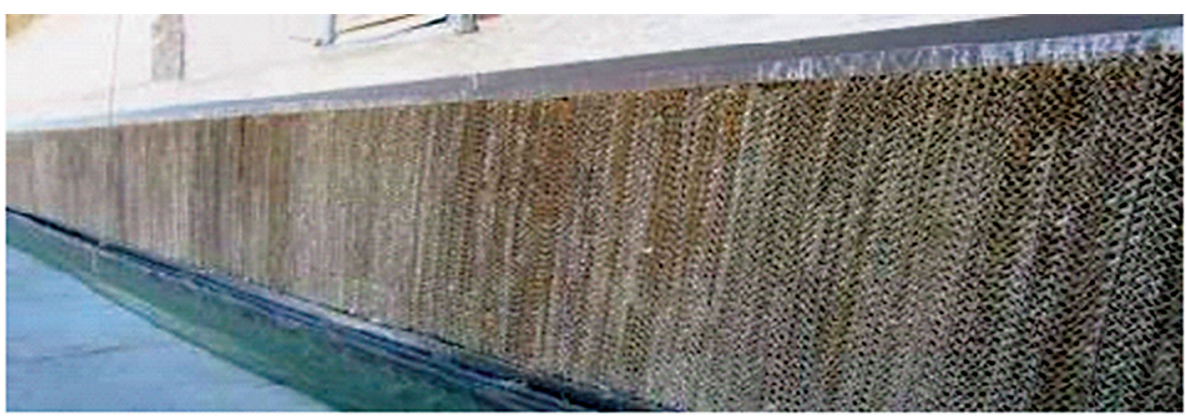

Figure 2. Evaporative pad cooling system 
The only potential problem with this system might be the humidity, which mustn't be too high. According to some calculations, with each degree of temperature lowering the humidity increases for $4.5 \%$. In that respect, in conditions of relatively high humidity, the system is not effective as it will introduce not only cool but also humid air, thus preventing appropriate heat release by panting.

Quite often during summertime, outside temperatures are $80^{\circ} \mathrm{F}-26.66^{\circ}$ $\mathrm{C}$, and relative humidity $80 \%$. Then, the temperature increases (late morning, afternoon) whereas relative humidity gradually decreases. During the night, the situation is opposite. It is important to know, in which period the relative humidity increases, e.g., from 10.00 p.m. to 10.00 a.m., when running of a pad cooling system would not be beneficial because it is difficult to evaporate water into air and get much cooling when the air already is $80 \%$ full of moisture (Czarick and Lacy, 2000). In any case, the system should not operate continuously for 24 hours, except in cases of tropical temperatures throughout the day and night. Additional nighttime cooling might be necessary for older birds or birds 2 weeks before slaughter (Dozier et al., 2005). In order to get efficient performance from a pad system, provide proper maintenance and operation. Allowing the pads to dry out overnight or at least once a day is highly important to prevent problems such as algae, collection of scale and dirt, which can reduce the life of the pads and water pump (Figure 3).

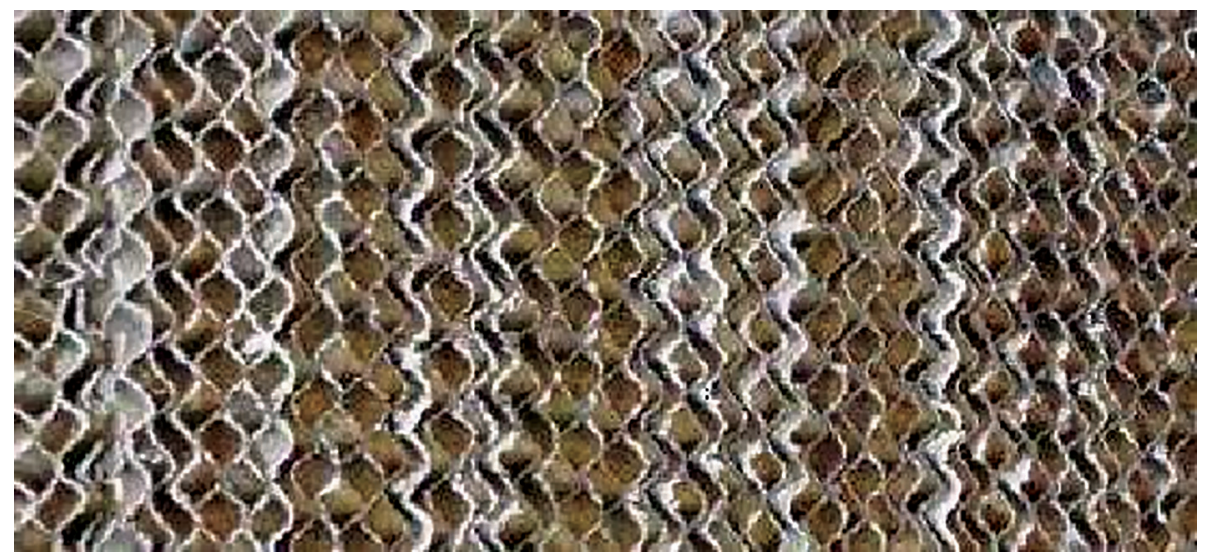

Figure 3. Scale deposition on the pads

A common question is, "When should the pads start running?" Often, farmers tend to run pads too soon (at lower temperatures) in an attempt to do what they think is best for their birds. In a poultry room with adequate 
air speed (minimum of $500 \mathrm{~m}$ on the foot; $600-700 \mathrm{~m}$ per minute is better), there is little benefit to running pads before about $82-85^{\circ} \mathrm{F}\left(27.77-29.44^{\circ} \mathrm{C}\right)$ (Dozier et al., 2005). Running the pads likely is counterproductive in terms of ambient conditions, production performances and overall health status of the flock (Campbell et al., 2006). Pad cooling system is complementary with tunnel ventilation and relies on the large volume of airflow produced by tunnel fans, which improves sensible heat release from the birds (Donald et al., 2000; Donald, 2000). To ensure proper functioning of a pad cooling system, it is important not to install sensors near the pads (Fig. 4), as this will tend to increase the possibility of pads coming on at too high a temperature for birds in the tunnel fan end (Fig. 5).

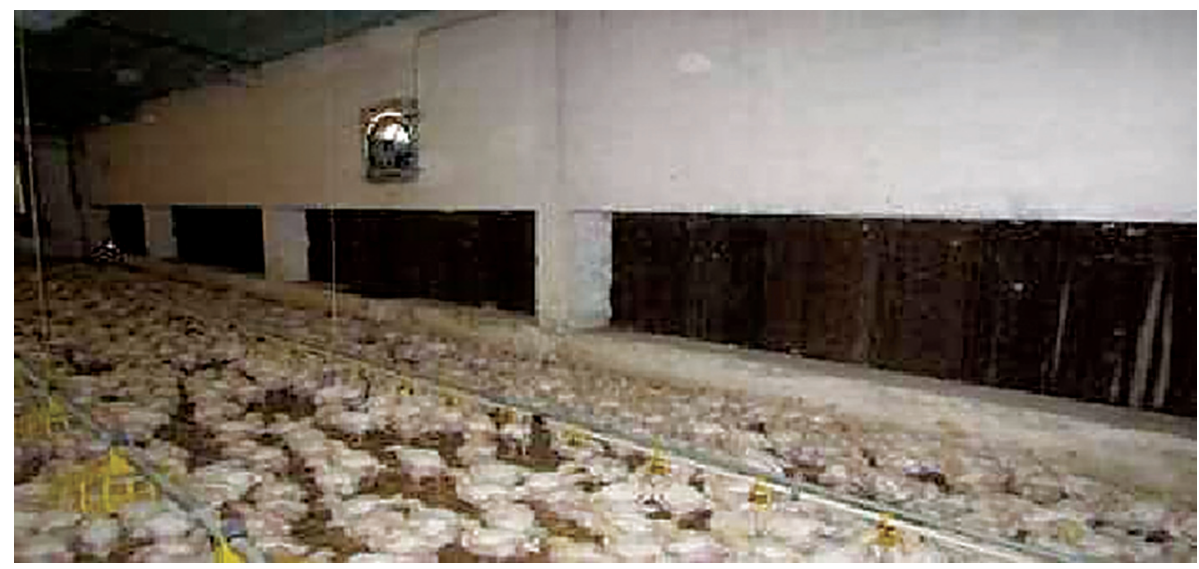

Figure 4. Grouping of chickens near the pads toward the cool place

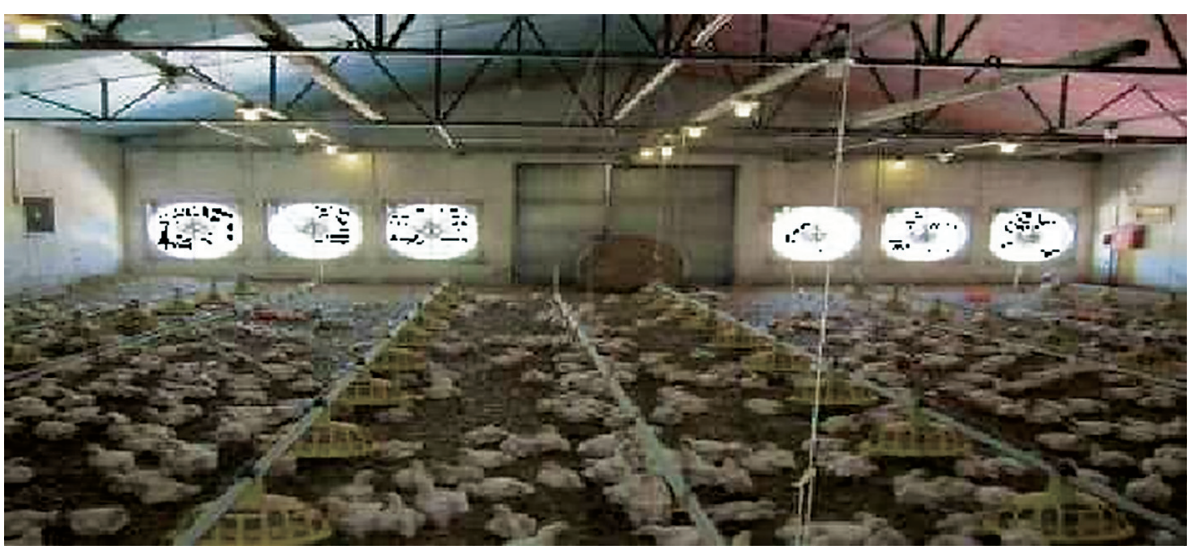

Figure 5. Reduced number of chickens at the end of the tunnel because of high temperature 


\section{Installation of evaporation cooling systems - foggers.}

Foggers spray droplets of cold water under high pressure forming a fog above the chickens thus cooling the surrounding air. These systems are applicable only in conditions of low humidity otherwise the droplets will not transport excess heat out of the room but leave a lot of additional moisture and wet the litter and the birds. It is of great importance to adjust the foggers with ventilation system and to properly maintain the equipment. The system is quite cost effective and efficient. However, it requires professional and permanent surveillance. Otherwise, in conditions of high air humidity and poor maintenance of the system, the owners often complain that:

- Often on hot afternoons, when they decide to turn on the foggers to improve the pad cooling, after some time they pick up a number of dead birds. It is due to the fact that running foggers actually increases the humidity and cannot remove excess heat and humidity from the production room

- Increase in humidity by fogger as well as lack of adequate maintenance of the ventilator can reduce the airflow for even $20 \%$ and more. Windspeed decrease from 500 feet per minute to only 300 feet per minute prevents proper heat release causing the birds to show signs of heat stress at temperatures as low as $78^{\circ} \mathrm{F}\left(25.55^{\circ} \mathrm{C}\right)$ (Czarick and Fairchild, 2003; Berma, 2008).

- High humidity of the air in the production facility can cause poor paw quality and generate production of ammonia from the litter

- Hard water results in scale deposits in the system and nozzle obstruction, which may cause wetting of the litter

3. Installation of in-house recirculation fans - air mixers. If any of aforementioned cooling systems is not feasible, increase of air velocity might be helpful. It can be accomplished by installing additional in-house fans, which are simple air-mixers that only accelerate the airflow. In this manner, the temperature of the air is not reduced but the airflow is increased, which can additionally cool the birds. Adequate (sufficient) number and proper positioning of fans inside the room is of crucial importance, as the birds will crowd around the fans with highest airflow. Any crowding of chickens could be detrimental. Migration fences can be used as a temporary solution to prevent too many birds to migrate towards one cooler until the appropriate fan regimen is accomplished.

\section{Floor cooling systems combined with tunnel ventilation}

Conduction (heat conduction) - some part of the heat can be transmitted 
through skin contact with cooler surfaces. Dry and loose litter enables the poultry to reach the cold floor beneath and lay down on it. Floor cooling operates similar to floor heating, in which cold water flows through the underfloor pipe system during the summer. The combination of underfloor cooling and tunnel ventilation system is highly effective and most promising solution. Some of its basic advantages are: the system is relatively cheap, easy to maintain and energy-saving. It should be emphasized that the system does not increase the air humidity in the poultry house. As compared with the systems known so far, combined cooling systems proved highly effective in terms of improving the production performances in poultry industry, and statistically significant differences were reported (Donald et al., 2000).
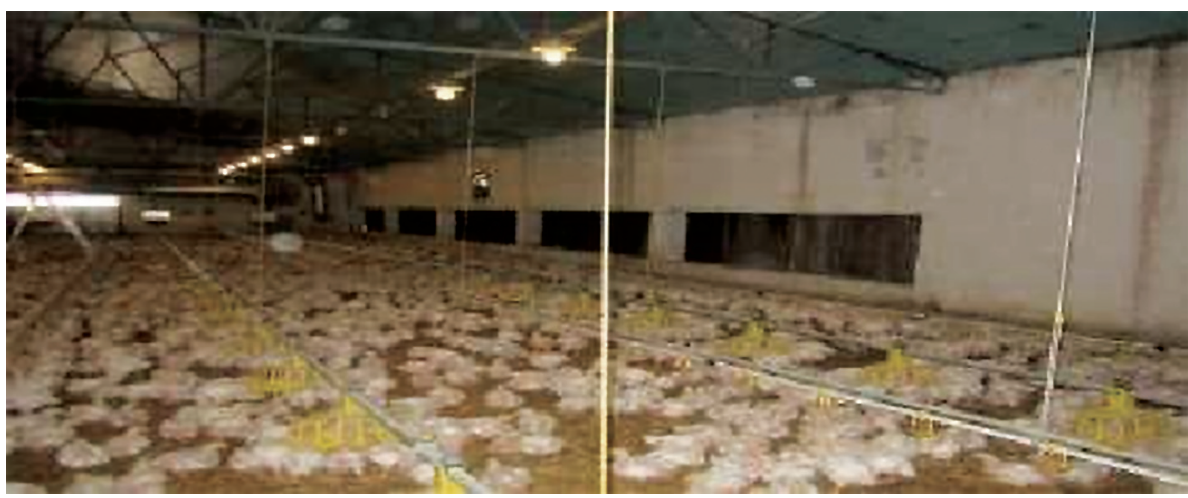

Figure 6. Proper distribution of chickens in the poultry house

\section{EFFECTS OF APPROPRIATE FEED AND WATER SUPPLY REGIMENT DURING THE PERIOD OF HEAT STRESS}

4. Water. During the heat stress, sufficient amounts of fresh cold water must be available to chickens. Cool water is required to enable heat release from the body. It is also necessary to provide additional waterers as the birds will consume more water. Water tanks should be properly insulated to prevent warming. It has already been emphasized that heat stress can induce heavy panting. Increased respiration rate results in release of substantial amounts of carbon dioxide and disturbance of blood acid-base balance as a consequence of decreased bicarbonate levels.

5. Food. With an increase of ambient temperature, the poultry will reduce the feed intake. Digestion and metabolism are associated with energy release and heating of the body, thus, the birds naturally avoid eating throughout the day. Feed removal not only prior to the hottest part of the day but some 
6-8 hour before (period required for digesting the feed) has been shown to be beneficial. In laying hens, dietary regimen should consist of $1 / 3$ of the ration early in the morning and $2 / 3$ late in the afternoon. Offering a night-time feeding is a good practice, as it will improve the quality of the eggshell. The composition of the feed mix should be properly adjusted and reformulated. Protein contributes more metabolic heat than fats, thus, it is necessary to formulate diets with lower protein levels and to utilize synthetic amino acids, especially methionine and lysine and increase the energy content rather through fats than carbohydrates. Hence, energy:protein ratio should be increased in favor of energy. Such formulations are readily digestible and easily metabolized with reduced heat release. Increased fat content requires supplementation of $\mathrm{E}$ vitamin as a stabilizer. Feeding management during extreme heat should consider highly digestible feed formulations. During heat stress pelleted feed should be preferred as it requires less energy for digestion.

Reduced feed intake and feed formulation adjustments will naturally result in changes of weight gain; however, this is negligible damage when compared to potential loss because of massive death. The same stands for the laying hens with an additional problem related to eggshell quality. The release of carbon dioxide through panting induces the increase of blood $\mathrm{pH}$ and consequent decrease in calcium bicarbonate levels, which is essential for eggshell formation. Disturbed mechanism of Ca transport in the blood contributes to poorer quality of eggshell rather than the level of calcium. Thus, supplementation of calcium to feed formulation will not be effective. Supplementation of electrolytes in the drinking water or feed is well accepted practice to compensate the loss. Some authors recommend supplementation of sodium bicarbonate, ammonium chloride and potassium chloride, and vitamins $\mathrm{C}, \mathrm{E}$ and $\mathrm{B} 2$ are recommended, also.

\section{CONCLUSIONS}

Monitoring of the presence and occurrence of particular infectious diseases during the research period as well as monitoring of production features and mortality structure revealed distinct changes. Considering that production on farms encompassed by this research involves modern technological procedures, the observed changes, above all those pertaining to the characteristics and structure of the mortality, are likely to be attributed to the effects of heat stress. In order to obtain more accurate data that would provide more 
precise conclusions further research is necessary along with the establishment of specific measurement system for assessing the effects of climatic changes on the observed parameters in poultry production.

Understanding of physiological features of poultry determining their defense mechanism against heat stress as well as the methods for alleviating impact of heat stress in poultry production will contribute to solving the problems and optimizing production features. It will also enable establishment of standards for measurement and monitoring of climatic changes and their effects on poultry production.

\section{ACKNOWLEDGEMENTS}

This investigation was financially supported by the Ministry of Education, Science and Technological Development, Republic of Serbia, Project No. TR 031071.

\section{REFERENCES :}

1. Berma A.: Increasing heat stress relief produced by coupled coat wetting and forced ventilation, Journal of dairy science, 91, 4571-4578, 2008

2. Campbell J., Donald J., Simpson G.: Keys to top evaporative cooling performance. Poultry Engineering, Economics, and Management Newsletter. Issue 41:1-4. May, 2006

3. Czarick M., Fairchild B.: Minimizing wet litter problems in houses with evaporative cooling pads. Poultry Housing Tips, 15, 5, 2003

4. Czarick M., Lacy M.P.: The 80-80 Rule.... and other facts about evaporative cooling. Poultry Housing Tips 12, 1-6, 2000

5. Donald J., Eckman M., Simpson G.: Keys to getting good performance from your evaporative cooling system. The Alabama Poultry Engineering and Economics Newsletter, 5, 2000

6. Donald J.: Getting the most from evaporative cooling systems in tunnel ventilated broiler houses, World Poultry, 16, 34-39, 2000

7. Dozier W.A., Lott B.D., Branton S..L.: Growth responses of male broilers subjected to increasing air velocities at high ambient temperatures and a high dew point. Poultry science, 84, 962-966, 2005

8. Kapetanov M., Potkonjak D., Milanov D., Stojanov I., Živkov-Baloš M., Prunić B.: Istraživanja raširenosti aspergiloze kod živine i mere kontrole, Zbornik Matice srpske za prirodne nauke, 269-278, 2011

9. Kapetanov M., Potkonjak D., Stojanov I., Živkov-Baloš M., Apić J.: Con- 
sequences of unsynchronized phisical and sexual maturity in breeder poultry flocks, Symposium 'New Technologies Incotempotary Animal production, 212-215, 2013

10. Kapetanov M., Potkonjak D., Stojanov I., Živkov-Baloš M., Jakšić S.: Uloga kliničke i patomorfološke dijagnostike mikotoksikoza izazvane T-2 toksinom kod roditeljskog jata u eksploataciji, Zbornik Matice srpske za prirodne nauke, 137-143, 2013

11. Levent, G.E.N.Ç., Portier K.M.: Sensible and latent heat productions from broilers in laboratory conditions. Turkish Journal of Veterinary and Animal Sciences, 29, 635-643, 2005

12. Simmons J.D., Lott B.D., May J.D.: Heat loss from broiler chickens subjected to various air speeds and ambient temperatures. Applied engineering in agriculture (USA), 1997

13. Stojanov I., Stojanović D., Ratajac R., Plavša N., Kapetanov M.: Promene osetljivosti Escherichia coli izolovane kod živine na antimikrobne lekove = Sensitivity of Escherichia coli strains isolated from poultry samples to antimicrobial drugs. Arhiv veterinarske medicine, 1, 1, 41-49, 2008

Primljeno: 25.12.2015.

Odobreno: 15.01.2016. 